\title{
PERAN TEKNOLOGI DALAM PROSES PEMBELAJARAN ERA COVID-19
}

\section{Desy Dahrina Fitri}

Email: 1910128120018@mhs.ulm.ac.id

Pendidikan IPS FKIP Universitas Lambung Mangkurat

\begin{abstract}
Abstrak
Pandemi Covid-19 telah menyebabkan perubahan besar pada hampir semua aspek kehidupan, salah satunya pada sistem pendidikan. Perubahan system pendidikan telah mempersulit peserta didik untuk menerima materi pembelajaran, karena pembelajaran yang biasanya dilakukan secara tatap muka menjadi pembelajaran jarak jauh. Tujuan penulisan ini untuk memperoleh pengetahuan pentingnya teknologi dalam proses pembelajaran era covic-19. Metode penulisan menggunakan metode studi pustaka. Teknologi telah bertindak menjadi bagian dari media dalam hubungan antara Guru dan peserta didik dalam proses mewujudkan pembelajaran secara online. Selain dari pada itu, Teknologi ini bertindak dalam memfasilitasi guru untuk dapat memberikan materi pembelajaran. Tentunya saat melaksanakan pembelajaran online, kendala terkait budaya akademik menjadi sebuah tantangan tersendiri untuk peserta didik diantaranya nilai, tingkah laku, pengetahuan, keahlian, keterampilan, maupun kesiapan dalam sarana dan prasarana. Selama pandemi, pemanfaatan teknologi dapat menjadi suatu solusi untuk mengatasi masalah dan tantangan dalam proses pembelajaran secara online terutama pada masa sekarang ini yang diharuskan selalu mengalami perubahan.
\end{abstract}

Kata Kunci: Teknologi, Pembelajaran, Pandemi Covid-19

\section{PENDAHULUAN}

Teknologi dan media pembelajaran saat ini hampir tidak dapat dipisahkan. Penggunaan teknologi yang banyak diminati banyak orang dan menjadikan teknologi sebagai media pembelajaran, tidak hanya memudahkan peserta didik dan pendidik dalam memperoleh 
informasi, tetapi juga memungkinkan peserta didik untuk menerimanya secara efektif. Tidak hanya bagi peserta didik saja, media teknolologi juga dapat meningkatkan kreativitas pendidik.

Di masa sekarang ini, dimana semua kegiatan dilakukan di rumah untuk mengurangi resiko penularan virus corona (Syaharuddin, S.,2020). Disertai dengan perkembangan teknologi yang sangat cepat dan manusia dituntut agar bisa mengaplikasikannya terlihat dengan adanya system yang sudah berbasis teknologi, dan mengharuskan penggunaan teknologi sebagai media pembelajaran merupakan keharusan di era sekarang ini.

Pembelajaran online merupakan solusi dari permasalahan yang dihadapi sekolah dan perguruan tinggi dalam system pendidikan (UH Salsabila, LI Sari, KH Lathif, AP Lestari, 2020). Dengan memberikan penjelasan dan pembelajaran secara baik dan jelas, maka peserta didik dapat melakukan pembelajaran online secara efektif dan optimal. Meskipun kegiatan pembelajaran tidak dapat dilakukan secara tatap muka, namun diharapkan pembelajaran secara online ini dapat dapat membuat peserta didik lebih mandiri dalam proses belajar mereka. Meskipun ada beberapa aspek positif dan negatifnya dari pembelajaran secara online ini, masih adanya beberapa kendala yang perlu dipertimbangkan. Misalnya, di beberapa area tempat peserta didik berada seperti sinyalnya yang lemah, kuota internet yang terbatas, selain itu kurangnya pemahaman dan pengetahuan mereka dalam menggunakan aplikasi atau media untuk mendukung suatu pembelajaran (S Riadi, EN Normelani, M Efendi, I Safitri, 2020).

\section{PEMBAHASAN}

Saat ini kemajuan teknologi saling berhubungan dengan adanya kemajuan IPTEK (ilmu pengetahuan dan teknologi) yang berguna untuk menunjang pembelajaran yang efektif dan efisien. Teknologi pendidikan tentunya akan menciptakan suatu pekerjaan yang bisa menjadikan proses belajar menjadi efektif dan efisien bagi setiap individunya. Hal ini, tentu saja selaras dengan hakikat teknologi pendidikan, yaitu penelitian dan praktik etis yang mendorong pembelajaran dan meningkatkan kinerja dengan menciptakan, menggunakan, dan mengelola proses dan sumber daya teknologi yang sesuai (Nurdyansyah, N.,2017).

Berdasarkan pengertian di atas, teknologi pendidikan dapat memberi manfaat sebagai penunjang dalam proses pembelajaran. Peran dari teknologi pendidikan meliputi: 1). Teknologi pendidikan menjadi sarana penunjang untuk menciptakan hal baru dalam pengetahuan. 2). 
Teknologi pendidikan berguna selaku wadah informasi agar peserta didik untuk memilih pengetahuan yang ada di dalamnya. 3). Teknologi pendidikan berguna sebagai suatu media untuk memajukan, memberikan fasilitas kepada peserta didik untuk berpendapat. 4). Teknologi pendidikan dapat menambah efektifitas dan juga efesiensi dalam pembelajaran (Nurdyansyah, N.,2017).

Media berbasis teknologi informasi saat ini yang mulai dikembangkan adalah aplikasi pembelajaran. Aplikasi pembelajaran adalah suatu perangkat lunak yang dirancang untuk menjalankan perintah tertentu sesuai dengan tujuan penggunaannya (Supriyanto, 2015; Dhanta, 2009, dalam H Susanto, H Akmal.,2018). Aplikasi pembelajaran adalah ide baru dan dapat digunakan dengan mudah oleh pendidik dan siswa kapan pun, di mana pun. Mehdipour dan Zerehkafi (2013: 95-96) menyebutkan beberapa keunggulan aplikasi pembelajaran, yaitu (1) memungkinkan pengguna untuk belajar kapan saja dan di mana saja, (2) fungsi-fungsi yang meliputi grafik, suara, bahkan animasi, dan (3) penyampaian yang fleksibel pesan pembelajaran, dan (4) Evaluasi hasil belajar dapat dilakukan secara mandiri oleh siswa (dalam $\mathrm{H}$ Susanto, $\mathrm{H}$ Akmal.,2018).

Selain itu, peranan teknologi pendidikan tentunya penting dalam sebuah proses belajar terutama saat terjadi pandemi seperti yang kita rasakan sekarang. Kemunculan virus corona mengharuskan semua kegiatan dijalankan di rumah masing-masing, sama halnya dengan kegiatan pembelajaran. Hal ini dilakukan guna memutus penularan dari virus corona tersebut, aktivitas belajar yang biasa di lakukan secara langsung (atau tatap muka) sekarang berubah menjadi pembelajaran yang dilakukan online.

Peran teknologi dalam pembelajaran sangatlah penting, hal ini dapat dilihat dari kondisi pandemi saat ini. Dengan adanya teknologi tentu memberikan kemudahan bagi guru dan juga siswa untuk belajar secara online. Ada berbagai macam platform yang disediakan untuk memfasilitasi pembelajaran jarak jauh, termasuk penggunaan Google Docs sebagai sebuah media untuk memudahkan pendidik agar bisa mengevalusia siswa, meskipun tidak secara tatap muka. Bisa juga dengan menggunakan forum diskusi online dengan Google. Formulir untukmengirimkan ujian, dan memberikan kuis melalui situs web atau aplikasi. Dengan mengakses berbagai situs web dan aplikasi (seperti jurnal, e-book, dan sumber terpercaya yang dapat mereka akses), teknologi juga dapat membantu siswa mengakses topik yang mungkin tidak 
tersedia dalam pembelajaran jarak jauh. Disisi lain, teknologi memiliki peranan untuk memajukan kreativitas bagi seorang guru maupun siswa atau peserta didik. Sebagai guru kita tentunya dapat menggunakan beberapa situs di berbagai media sosial (seperti Instagram, Youtube, dll) untuk berinovasi dalam memberikan materi pembelajaran. Layaknya pendidik, siswa dapat menggunakan berbagai situs media sosial untuk menyelesaikan pekerjaan rumahnya. Dalam hal ini, teknologi dapat mendukung keberhasilan dalam proses pembelajaran online yang dilakukan pada kondisi pandemi saat ini.

Keberhasilan dalam pembelajaran online bukan dipengaruhi oleh teknologi internet saja melainkan kualitas SDM juga dapat mempengaruhi hal tersebut. Jika operator maupun pemakai tidak mempunyai pengetahuan juga keahlian yang bagus dalam menggunakan maupun mengelola teknologi tersebut, tentunya teknologi internet enggan memberi dampak yang baik juga. Oleh karena itu, pengetahuan mengenai teknologi menjadi salah satu tolak ukur keberhasilan dalam pembelajaran online. Teknologi internet memegang peranan yang sangat penting dalam pembelajaran online, karena jika tidak ada teknologi internet tersebut akan memberikan hambatan dalam proses belajar online. Teknologi internet dapat memberikan pengaruh untuk siswa egar menemukan materi yang tidak mereka mengerti. Selain Teknologi internet aplikasi pembelajaran pun memberi banyak manfaat sebagai penunjang dalam proses pembelajaran untuk mempermudah dalam memahami materi pelajaran (H Susanto, $\mathrm{H}$ Akmal, 2018).

Peran guru sebagai pendidik tidak bisa digantikan oleh mesin (teknologi). Kemampuan guru dalam hal rasa, bahasa dan pembentukan karakter membuat siswa menunggu kemunculannya kapanpun dan dimanapun. Teknologi yang diciptakan dirancang untuk memudahkan pekerjaan manusia, termasuk dalam proses pembelajaran. Perpaduan kedua hal tersebut menjadi solusi yang tepat terutama untuk pembelajaran di era pasca COVID-19 (Syaharuddin, S.,2020).

Virus corona berdampak signifikan pada berbagai sektor, salah satunya adalah sektor pendidikan. Untuk mencegah penyebaran virus corona, semua negara telah menggunakan berbagai macam kebijakan untuk mencegah penyebaran virus ini, salah satu upayanya yaitu dengan isolasi fisik. Di indonesia pemerintah telah menerapkan kebijakan PSBB ( PembatasanSosial Besar-Besaran), yang membuat semua aktifitas hanya bisa dilakukan dalam 
rumah. Hal ini mencakup kegiatan kerja hingga kegiatan belajar yang hanya dilakukan di dalam rumah, adapun tujuannya untuk mencegah serta mengurangi penyebaran dari virus corona.

Sesuai kebijakan ini, kegiatan pembelarajan terpaksa dilakukan secara online. Pembelajaran onlien adalah suatu cara pembelajaran yang dilakukan tidak secara lamgsung dan tentunya tidak berada ditempat yang sama melainkan penggunaan platform, meskiiun platform tersebut dapat dilakukan dari jarak jauh, platform tersebut juga dapat membantu proses belajar mengajar. Dengan perkebangan teknologi yang sangat pesat, komunikasi serta informasi dari berbagai macam platform (misal Google Clasroom dan E-learning) dapat digunakan untuk menyelesaikan pembelajaran online. Selain itu, beberapa aplikasi dapat digunakan untuk pembelajaran online dalam bentuk konferensi video, termasuk aplikasi "Via Zoom" dan "Google Meet". Selain menggunakan aplikasi tersebut, Whatsapp Group kerap menjadi cara alternatif untuk mencapai pembelajaran online (Syaharuddin, S.,2020).

Dalam melaksanakan pembelajaran online pada kondisi pandemi seperti sekarang, tentunya akan terdapat macam-macam kendala. Mengingat pembelajaran online harus terus berlanjut selama pandemi Covid-19, kendala tersebut sendiri akan menjadi sebuah tantangan bagi siswa dibidang pendidikan itu sendiri, terutama untuk pendidik dan juga peserta didik. Realisasi pembelajaran online itu sendiri tidak lepas dari jaringan internet, oleh karena itu kendala pelaksanaan pembelajaran online semacam ini adalah selain kurangnya perangkat internet, sulitnya mendapatkan akses internet yang sudah menjadi hal yang lumrah. Salah satu penyebabnya adalah lokasi geografis (S Riadi, EN Normelani, M Efendi, I Safitri.,2020).

Bersamaan dengan adanya pandemi Covid-19 ini, telah memaksa semua pihak agar dapat menyesuaikan diri dengan keadaan dan situasi baru. Dalam lingkup pendidikan, baik pendidik maupun peserta didik harus mampu mengoperasikan sistem pembelajaran online dengan baik. Kesiapan sumber daya manusia merupakan bagian terpenting dari keberhasilan realisasi pembelajaran online. Kesiapan ini terkait dengan kemampuan pendidik dan peserta didik dalam menggunakan dan mengolah berbagai sistem teknis yang digunakan dalam proses pembelajaran online. Berawal dari model tradisional, model pembelajaran online tiba-tiba berubah sehingga menyebabkan sedikitnya persiapan yang memadai, lalu menjadikan pembelajaran secara online belum menjadi yang terbaik. Bagi para Guru dan peserta didik, hal ini merupakan tantangan 
tersendiri, sehingga mereka harus segera beradaptasi dengan masa pandemic dimana keahlian sistem pengoperasian teknologi yang saat ini sudah menjadi kebutuhan penting.

Selain itu, kendala pembelajaran online datang dari siswa. Dibandingkan dengan pembelajaran tatap muka, antusiasme belajar siswa dalam proses pembelajaran online mengalami penurunan. Menurunnya motivasi belajar siswa disebebkan oleh faktor, seperti keadaan selama kegiatan pembelajaran online yang menuntut siswa agar belajar di rumah sendiri, sehingga mereka terpaksa untuk belajar serta memahami topik pembelajaran dengan mandiri dan tidak adanya pendidik yang mendampingi serta mengajarkan topik kepada siswa. Hal ini tentunya dapat menyebabkan ketidak mampuan guru untuk mengambil sebuah tindakan, seperti penghargaan dan hukuman, insentif, dan kutukan. Perilaku pendidik tersebut dapat meningkatkan motivasi siswa. Selain keefektifan waktu belajar juga berpengaruh terhadap motivasi belajar siswa. Siswa merasa kesulitan untuk menentukan menentukan waktu yang pas saat belajar di rumah pada saat ini. Adapun lingkungan sekitar seperti keluarga yang tidak menguntungkan menghalangi siswa untuk fokus pada studi mereka. Melihat kendala tersebut menjadi tantangan tersendiri bagi para pendidik dan peserta didik. Pendidik dituntut untuk lebih inovatif dalam menentukan cara atau metode penyampaian materi agar siswa dapat dengan mudah menerimanya meskipun tidak disampaikan secara tatap muka. Pada saat yang sama mahassiswa dituntut agar mampu beradaptasi keadaan yang kita alami saat ini. Perlu kita ketahui bahwa terdapat berbagai macam tantangan dalam dunia pendidikan selama terjadinya pandemi covid-19, sehingga menyebabkan budaya akademi seperti nilai, pengetahuan, keteramapilan dan kesiapan sarana yang terkait dengan literasi teknis.

\section{SIMPULAN}

Teknologi pendidikan berbasis teknologi berguna untuk menciptakan sebuah proses pembelajaran yang efektif dan efesien. Teknologi pendidikan lebih pada teknologi mengevalusi kegiatan belajar ataupun teknologi yang dilaksanakan saat ini. Teknologi pendidikan memberikan peranan untuk mendorong pembelajaran, dan dapat juga untuk meningkatkan kinerja sistem dengan membuat menejemen proyek teknologi pendidikan. Teknologi pendidikan juga bisa menjadi teknologi yang mendukung dalam metode pembelajaran yang dilakukan dalam proses pembelajaran tersebut. Teknologi pendidikan tentunya dapat mendukung pembelajaran yang dilakukan dalam dunia pendidikan agar tujuan yang diharapkan dapat bisa 
tercapai.Teknologi pendidikan itu dapat mempengaruhi proses pembelajaran untuk mendukung sistem pembelajaran yang dilaksanakan.

Di era pandemi sendiri, peran teknologi dalam pembalajaran membutuhkan pelaksanaan pendidikan yang dilakukan secara online di rumah masing-masing. Kegiatan pembelajaran onlien ini tentunya memiliki tujuan untuk meminimalkan penyebaran dari virus corona. Adapun tingkatan keberhasilan dalam pembelajaran online sendiri dipengaruhi oleh bebrapa sebab seperti peran teknologi dan juga kualitas dari Sumber Daya Manusia (SDM). Jika SDM yang merupakan pemakai mempunyai pengetahuan yang baik, dan memiliki keahlian yang baik pula dalam pemakaian dan juga penanganan teknologi, maka teknologi akan berdampak signifikan juga.

\section{REFERENSI}

Bambang Subiyakto, Abbas. W.E, Syahruddin, Mutiani. (2020) STRATEGI PEMBELAJARAN IPS ; KONSEP DAN APLIKASI.

Nurdyansyah, N. (2017). Sumber Daya dalam Teknologi Pendidikan. Universitas Muhammadiyah Sidoarjo.

Rahman, A. M., Mutiani, M., \& Putra, M. A. H. (2019). Pengaruh kompetensi pedagogik dosen terhadap motivasi belajar mahasiswa pendidikan IPS. Jurnal Darussalam: Jurnal Pendidikan, Komunikasi dan Pemikiran Hukum Islam, 10(2), 375-387.

Riadi, S., Normelani, E. N., Efendi, M., Safitri, I., \& Tsabita, G. F. I. (2020). Persepsi Mahasiswa Prodi S1 Geografi FISIP ULM Terhadap Kuliah Online Di Masa Pandemi Covid-19. PADARINGAN (Jurnal Pendidikan Sosiologi Antropologi), 2(2), 219-227.

Suminar, D. (2019, May). Penerapan Teknologi Sebagai Media Pembelajaran Pada Mata Pelajaran Sosiologi. In Prosiding Seminar Nasional Pendidikan FKIP (Vol. 2, No. 1, pp. 774-783).

Susanto, H., \& Akmal, H. (2018). Efektivitas Penggunaan Aplikasi Pembelajaran Berbasis Mobile Smartphone Sebagai Media Pengenalan Sejarah Lokal Masa Revolusi Fisik Di Kalimantan Selatan Pada Siswa Sekolah Menengah Atas. HISTORIA: Jurnal Program Studi Pendidikan Sejarah, 6(2), 197-206. 
Syaharuddin, S. (2020). Menimbang Peran Teknologi dan Guru dalam Pembelajaran di Era COVID-19. Menimbang Peran Teknologi dan Guru dalam Pembelajaran di Era COVID19.

Syaharuddin, S. (2020). Pembelajaran Masa Pandemi: Dari Konvensional Ke Daring. Pembelajaran Masa Pandemi: Dari Konvensional Ke Daring. 